\begin{tabular}{|l|l|l||}
\hline \multicolumn{2}{|c|}{ PublisherInfo } \\
\hline \hline PublisherName & $:$ & BioMed Central \\
\hline \hline PublisherLocation & $:$ & London \\
\hline \hline PublisherImprintName & $:$ & BioMed Central \\
\hline \hline
\end{tabular}

\title{
Moth mating
}

\begin{tabular}{|l|l|l||}
\hline \multicolumn{2}{|c|}{ ArticleInfo } \\
\hline \hline ArticleID & $:$ & 4622 \\
\hline \hline ArticleDOI & $:$ & $10.1186 /$ gb-spotlight-20021028-02 \\
\hline \hline ArticleCitationID & $:$ & spotlight-20021028-02 \\
\hline \hline ArticleSequenceNumber & $:$ & 288 \\
\hline \hline ArticleCategory & $:$ & Research news \\
\hline \hline ArticleFirstPage & $:$ & 1 \\
\hline \hline ArticleLastPage & $:$ & 2 \\
\hline \hline & & RegistrationDate : 2002-10-28 \\
ArticleHistory & $:$ & OnlineDate $\quad$ 2002-10-28 \\
\hline \hline ArticleCopyright & $:$ & BioMed Central Ltd2002 \\
\hline \hline ArticleGrants & $:$ & \\
\hline \hline ArticleContext & $:$ & 130593311 \\
\hline \hline
\end{tabular}




\section{Jonathan B Weitzman}

Email: jonathanweitzman@hotmail.com

Female arctid moths (Utetheisa ornatrix) prefer to mate with large males. There is evidence that the female benefits both phenotypically and genetically. In the October 24 Nature, Sabeti et al. describe their analysis of the genetic basis for female mate preference (Nature 2002, 419:830-832). They calculated a 'mating preference index' (MPI) for female moths and found that mating preferences of daughters were primarily inherited from the father. There is also a correlation between female MPIs and their father's body size - daughters with large fathers have a stronger preference for larger males. Utetheisa males are homogametic (ZZ) and females are heterogametic (ZW), so the genes involved in mating preference can be assigned to the $Z$ chromosome. The authors speculate that $Z$-linkage of female preference may be a general feature in the Lepidoptera.

\section{References}

1. Female choice increases offspring fitness in an arctiid moth (Utetheisa ornatrix).

2. Nature, [http://www.nature.com] 